\title{
昭和40年代に開発された郊外大 RESEARCH OF THE SUBURBAN 規模分譲集合住宅団地の維持管 CONDOMINIUM HOUSING ESTATES 理に関する実態調查 DEVELOPED BETWEEN 1965-75
}

\section{曽根陽子 一 $* 1$ 北崎利恵 一 $* 2$}

キーワード :

分誶集合住宅，維持管理，管理組合活動，昭和 40 年代，郊外

Keywords :

Condominiums, Maintenance \& management, Owners association activity, 1965-75, Suburb
Yoko SONE $-* 1 \quad$ Rie KITAZAKI $-* 2$

This is the report about the suburban condominium housing estates developed between 1965-75. We investigated the owners association activity such as the maintenance \& management and the trend of the tenant occupancy. According to these investigations, most of these condominiums are in good condition in terms of largescale repairs and the reservation of funds for repairs. We classified and categorized them depending on their characters. It is reasonable to conclude that each group has own way of renewal.

\section{1.はじめに・調査概要}

昭和40年代、日本住宅公団は、同一タイプで小規模な住戸による 分譫集合住宅を都市郊外に大量供給した。その団地は500戸を越え る規模のものが多く、4半世紀後の現在、居住者の老龄化と建物の 老朽化、スラム化が心配されている"。松本、山本氏ら 21 はこれら の数団地を対象とした詳細な実態調査を基に、その実態と問題の所 在を厳しく指摘してきた。

昭和 40 年代の大規模郊外分譲住宅団地 ${ }^{3}$ は、今後建物出化が進行 し、建て替え問題が生じても、立地条件と団地規模、居住者の老齢 化等から、再生の合意形成が極めて困難であろうと予想される。と すれば居住者の老齢化が進行しつつある現在、維持管理の状態や居 住者の動向、管理組合活動など、これら団地の全体像を把握し、早 急に社会的対応を考えなければならない。

上記団地は首都圏で39団地（45管理組合－36,123戸）あるが、長 い時間経過の間に、駅の新設や周辺開発等によって立地条件に差が 生じている。また建設年度や住戸規模などの初期条件の微妙な違い もその後の居住者動向に影響を与え、管理組合活動の違いもあり、 団地によって再生の方向は一律でないと思われる。本報告は、上記 45管理組合のうち建て替え進行中の団地と駅至近にあり等価交換可 能な団地を除く38管理組合の理事長に対する諥送アンケート調査

（42項目）を行い、その結果（回答30組合）をまとめたものである。 調查時期は平成 10 年 1 月下旬。回収は 3 月上旬まで。同時に交通 の便、周辺環境、維持管理状況、中古価格等の実地観察調査を行い、 5 団地についてはヒヤリング調査も実施した。

\section{2. 調查結果}

2-1. 管理組合の活動状況

2-1-1. 理事会活動など

管理組合規約の規約改正は、8割（24/30）が実施している。内容 は表 1 のとおりで、「区分所有法の改正」に伴うものが多い。

理事会は全ての組合で月 1 回以上行われており、毎月の定例理事 会の他、総会前の $2 \sim 3$ 回を加えた、12〜15回という回答が 8 割

(24/30) を占めている。年36回、24回、という回答は、特定の事項 （駐車場増設問題など）の別組織委員会会合を加えた数であろう。 特定課題の検討組織をもつ組合は約 7 割 $(22 / 30)$ で、内容は表 2 の とおりである。

委任状を含む総会の出席者は（回答数22）、平均すれば 8 割だが、 出席率が 9 割を越えるのが 5 組合ある。直接出席率（回答数28）の 平均は1.2割で、最高が 3 割である。図 1 は団地規模と直接出席率の 関係を示しているが、団地規模が大きくなると直接出席率が低くな る、ゆるい逆比例関係になっている。

2-1-2. 增改築等改善工事の実施状況

住棟の増改築は 4 組合で行われており、全て南面バルコニーの先

表 1 管理組合規約改正内容

\begin{tabular}{|c|c|}
\hline & 国蓉䎦 \\
\hline • 区分所有法の改正に対応 & 8 \\
\hline - 全文改正 & 2 \\
\hline .「日住協等ひモデルに淮拠 & 2 \\
\hline 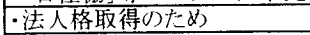 & 1 \\
\hline ·增筑ひため & 1 \\
\hline -宅の他(組合運営関倸) & 4 \\
\hline
\end{tabular}

表 2 特定課題の検討組織

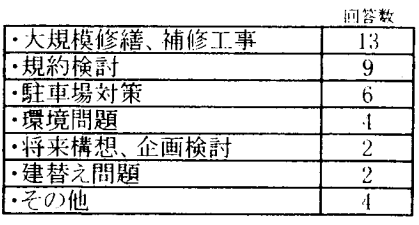

*1 日本大学生産工学部建築工学科 教授・工博

（宁275-8575 習志野市泉町1-2-1）

*2 蛛都市整備プランニング計画本部住宅整備部
*1 Prof., Dept. of Architecture and Architectural Engineering, College of Industrial Technology, Nihon Univ., Dr. Eng.

*2 Urban Planning \& Engineering Co. 
に6 畳2 室を增築したタイプのもの（図2）である。

集会所は、増築、全面建て替え、全面改修など、6割（18）の団 地が何らかの改良工事を行っている。集会所以外の改善工事は、防 水、電気・ガス設備更新等、現状維持的なものがほとんどである゙〉。 改善を行ったという回答は 6 割だが、実地調查によれば全ての団地 が歩道舗装や自転車置き場などに小改善を行っている。

駐車場は完成当時の設置率が低く、1 団地を除く全ての団地が増 設工事をしていた。ただ増設台数には大きな差があり、現在でも11 組合が「改善すべき点」として駐車場をあげている。駐車場增設を 巡って「増設と緑の保存」(6)「増設賛成だが自分の所はだめ」(2) の居住者の意見対立がある団地が多い。「大型化でスペース拡幅」

(3)「料金改訂」「立体化」「違法駐車パトロール」などを検討し

ているという回答もあった。

\section{2-2.大規模修縉の実施状況}

\section{2-2-1. 共益費、修績積立金について}

修繥積立金、共益費十修䋹積立金の金額別組合数は図 3 のとおり。 共益費より積立金の方が高い団地がほとんどで、同額または共益費 が低いのは 3 組合しかない。積立金は共益費の2.1倍(平均)である。 積立金の戸当平均は年額 108,200 円、最高は216,000円、次いで180， 000円である5 。最低が48,000円、次いで54,000円である。民間を 含む分譲集合住宅全体の戸当積立金は、年額 48,000 円までが 7 割で あるから ${ }^{6) 、}$ 調查対象団地が極めて高い積立金であると分かる。合 計額の最少は78,000円、最高が288,000円で、3.7倍の差がある。合 計金額が20万円を超える 4 組合は全て近 3 年以内に值上げしている。

修繽積立金の戸当たり残高は表 3 のとおり。半数の組合が10～50 万円で積立金の平均額 108,200 円の 1 年〜 5 年分の範囲にある。 100 万円以上の積立金がある 3 組合は全て来年度に大規模修繥の予定で ある。積立金の赤字は 1 組合だけで、外壁を87年に92、93年に給排水

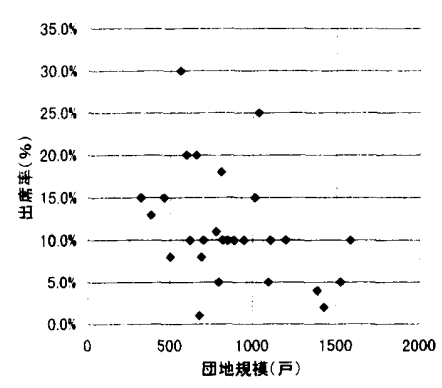

図 1 総会出席率と団地規模

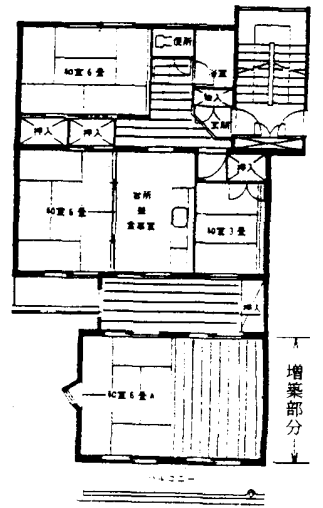

図 2 増築住戸平面図

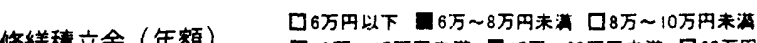

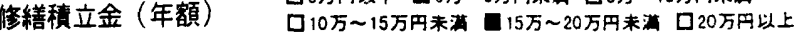

\begin{tabular}{|c|c|c|c|c|}
\hline 1030 & $13.8 \%$ & $27.6 x$ & $34.5 x$ & 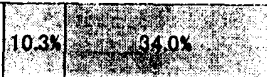 \\
\hline
\end{tabular}

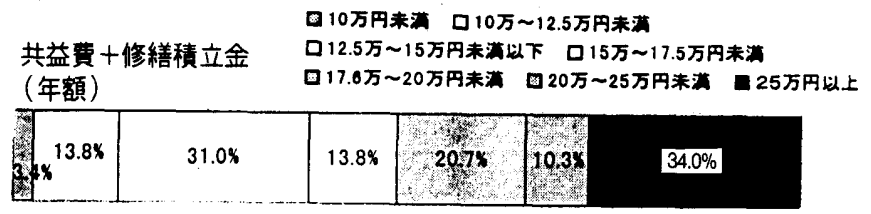

図 3 戸当たりの修繕積立金、共益費十修績積立金
管工事を借入金と積立金で実施し、戸当4万余の赤字になっている。 積立金残額が10万未満の 6 組合は近 3 年以内に防水、外壁、給排水 管の 2 つ上上の改修工事を実施しており、順当な大規模修繥の結果 として、積立金が減少したと見ることができる。

積立金の增額回数は表 4 の通りで、平均は 4.28 回である。半数が この 3 年以内に増額している。10年以上増額していないのは 2 組合 だけだが、その一方は昨年まで建て替え問題を検討しており、他方 は14年前の大幅增額で12万円に值上げしている。後者は積立金増額 の次年度に外壁改修を、その 8 年後に防水改修をしている。どちら も築15年、23年後の調查団地中最も遅い改修であったが、その後は 修繥周期を守って外壁改修している。積立金の残額も51〜99万円あ り、現在では大規模修絴実施上の問題はなくなったと思われる。

\section{2-2-2.長期修績計画の有無}

長期修縉計画は 9 割が「有り」と回答している。「ない」のは 3 組合だけだが、1 組合は土事毎の直営発注方式で必要な改修工事を 行っている。残り 2 組合（1組合は作成準備中）も外壁、防水の大 規模修縉を周期を決めて実施しており、今後の予定も書かれている ので、長期修繥計画が全くない状態ではない。

\section{2-2-3.大規模修緬の実施状況}

表 5 の通りである。屋上防水に関しては、ほば半数の組合が標準 周期7)通りに 1 回目の修繵をしている。1 回目の防水が極端に遅か った 2 組合のうち、1 組合はその後修緗積立金を大幅増額しており、 もう 1 組合も外壁は順調な周期で改修し、給水管改修も行っている。 外壁は 7 割が12年以下で改修しており、それ以外も全て、15年以内に 実施している。その後の周期も外壁の方が防水より短い。実地調查 によれば、どの団地も（1団地は補修中）外壁、外構共きれいに維 持管理され、隣接する公団賃貸が污れているのと対照的であった。

給水管ライニングエ事は、全ての団地が既に標準的周期を迎えて いるが、実施しているのは2/3 (20組合) である。また実施済みでも 時期はやや遅れている。排水管については、実施済みは 9 組合のみ で、実施予定があるのは 7 組合（ほとんどが 1 年以内実施）、約半 数が今後の実施時期の記入がない。

費用の調達方法は、過去の大規模修繥実施時には修繥積立金で賄 ったのは 6 割強 $(19 / 29)$ で、それ以外の 4 割は何らか他の資金調達 が必要であった。別途特別積立金 $(2,000$ 円 $\times 26$ 回/戸) 徵収 (1)、 積立金增額 (2)、金融公庫や銀行からの借入金併用(7)などである。 今後の費用調達は全組合が「修縡積立金から」と回答しているが、 残額が少なくなっている組合もあり、劣化の進行程度によっては、 更に傎上げや借入が必要になるところも出てくると思われる。

\section{2-3.今後の再生計画}

\section{2-3-1. 今後の改善すべき検討内容}

今後改善すべき検討内容として理事会で話題に上がっている内容 は表 6 のとおり。建物については、防水や外壁、排水管工事など

\section{表３戸当たり修繥積立金残高}

\begin{tabular}{|l|c|}
\hline$\cdot$ 赤字 & 回答数 \\
\hline$\cdot 10$ 万円未満 & 1 \\
\hline$\cdot 10 \sim 50$ 万円 & 6 \\
\hline$\cdot 51 \sim 100$ 万円 & 16 \\
\hline$\cdot 100$ 万以上 & 4 \\
\hline
\end{tabular}

表 4 修繥積立金増額回数

*有効回答: 30 団地

\begin{tabular}{|l|c|}
\hline$\cdot 0 \sim 2$ 回 & 3 \\
\hline$\cdot 3 \sim 5$ 回 & 15 \\
\hline$\cdot 6 \sim 8$ 回 & 4 \\
\hline .9回以上 & 2 \\
\hline
\end{tabular}

*有効回答:24団地 
大規模改修の内容と、比較的簡易な工事内容のものである。団地内 施設に関しては駐車場の話題が最も多いが、全体の設備改善、グレ ードアップなどの他、これまでにない防災倉庫(1)があがっている。 具体的検討に入っている課題は、多くが大規模改修に関するものだ が、電気容量アップ、防災池兼公園、共用ロッカー、長期修䋥計画 の 5 年毎見直し、駐車場立体化など、改善的なものもある。これら の改善を実施するための費用調達は、改修修縜に関するものはほと んどが「修繥積立金」からと回答し、その他は「駐車場料金」「駐 車場數金増額」「一時金」「借入」「積立金增額」などである。

\section{2-3-2.住宅建物の陳腐化と新たに欲しい施設}

建物機能が陳腐化した部分について、各項目別の数を多い順にあ げると、電気容量 $(25 / 27)$ 洗濯排水 $(20 / 27)$ 浴室まわり $(12 / 27)$ 内 部遮音(11/27) TVアンテナ (10/27) 階段室まわり (7/27) 、外部 遮音(6/27) である。だが実現あるいは実現が具体化しているのは半 数以下 (12/27) である。更に、管理組合が実現に直接関与している のは 3 組合だけである。電気容量 $(30 \mathrm{~A})$ は陳腐化の回答が多いが、 具体化しているのが 1 組合、既実施が 1 組合だけである。

新たに欲しい施設は（複数選択回答、回答数24）駐車場(15)が最 も多い。ゲストルーム(11)は伝統的生活習慣が変わって来たので、 今後の集合住宅に求められた施設であろう。居住者老齢化に対応し て高齢者施設に対する要望も高い $(10)$ 。坚童・保育施設、飲食施設、 コンビニなどに対する希望はほとんどない。

\section{2-3-3.建て替えについて}

建て替えについて（回答数29）、「一部の間で」(8)と「出ていな い」(12)を合わて70\%の団地が建て替えを切実なものとしていない。 特別課題の検討組織で「建て替え」を回答した 2 組合も「一部の 間」だけである。4 組合は過去に検討したが現在は活動中止してい る。「居住者の老齢化で今後の課題」など全体に消極的である。 「今後検討の予定」は 5 組合で、さらに積極的に「長期計画のスケ ジュールに入っている」のは 1 組合のみであった。

もし建て替えるとした時の障害（複数選択回答、回答数28）につ いては、上位から居住者高年齢化 (22/28) 等価交換不成立 $(19 / 2$ 8) 資金不足 $(12 / 28)$ 貢貸化進行(11/28) などで、老路化が最上位で ある。過去に建て替えを検討した 4 組合は、バブル崩壊で等価交換 不成立（3）貢貸化（3）などの経済的要因による中断と答えている。 2-4. 入扂者動向

\section{2-4-1. 当初からの入居者}

回答数22。多い順にあげると6 割（1）5 割（1）4割（3）などで、

表 5 大規模修繥の実施状況

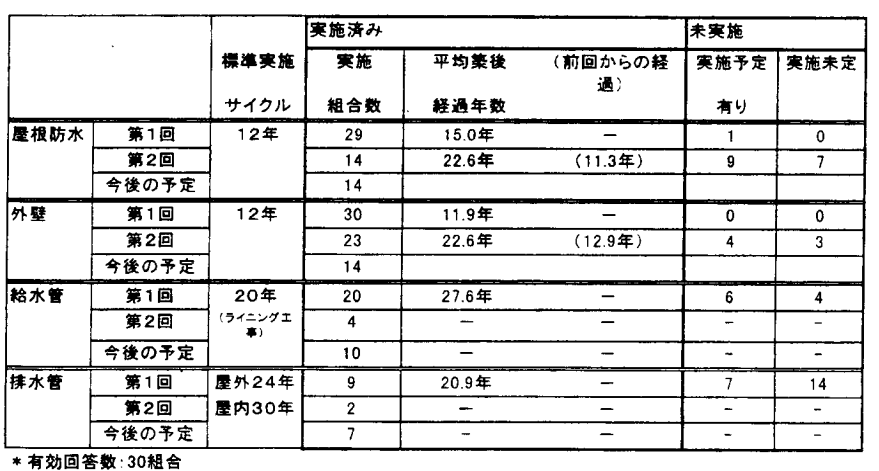

いずれも駅からバスを使用する団地である。低いのは0.6割（1） 1 割（1）の 2 団地だけで、多くは 3 割前後である。

\section{2-4-2．借家人}

回答数 28 。20\%を越えるのが 5 団地で、18\%〜が 4 団地ある。放 射状線から徒歩圏にあるなど交通の便の良い団地が多い。10\%以下 は 9 団地で、バス利用が多く(8/9)、鉄道も京成線、相模鉄道、東 武伊勢崎線、京急逗子線など支線も多い（5）。平均13.3\%である から、全国の昭和40年代マンションの賃貸率 $20 \%{ }^{61}$ に比べ少ない。 借家人率と空き家率の相関はなく（図 4)、売却できないため借家 にしているのでなく、需要があり、売るより有利なので貸している という場合が多いと思われる。

\section{2-4-3.過去 5 年間の区分所有者の移動}

回答数22。区分所有者の移動は、どの組合も詳しい数字をあげて いる。過去 5 年間の移動傾向は、平成 6 年（バブル）に上がったが、 全体には横這い傾向である。平均移動率には大きな開きがあり、1 \%前後が 3 団地、5\%を越えるのが 3 団地である。区分所有者の平均 移動率と入居時からの居住者率をみると、ゆるい逆比例関係にある （図 5)。空き家率は 1 組合 (移動率高い) を除いて全て $5 \%$ 以下 で、空き家化は進行していない。3\%以上の移動率のある団地で住 户規模の平均が $60 \mathrm{~m}$ を越えるものはない。

\section{2-4-4.その他}

親子近居世帯については（回答数26）「知らない」(4)又は「有 る」(22) と回答しているが、戸数を正確に把握している組合はない。 近年転入者の家族構成（複数選択回答。回答者数26）は、若年夫婦 $(14 / 26) 、 30$ 代核家族 $(9 / 26)$ 、高齢夫婦 $(7 / 26)$ 、若年単身者 (6/26) が多い。

高齢者のみの世帯、高齢単身者世帯（回答者数16）は、3.5割〜0. 25割まで比率のバラッキが多いが、ほとんどの団地が高齢単身者よ り高齢者夫婦の方が数倍多いと回答している。ヒヤリングでは、過 去に家族構成などの調査を行ったことのある組合 (3/5) が多かった。

表 6 今後改善すべき検討内容

\begin{tabular}{|c|c|c|c|}
\hline 改萻の铦姆 & ( 项目) & (䉙所·内容) & 回答組合数 \\
\hline \multirow[t]{4}{*}{ 建物の改警·改善 } & 㕫水 & 階段童 & 2 \\
\hline & 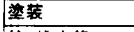 & 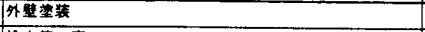 & 2 \\
\hline & 粭·钮水管 & 津水管工革 & 1 \\
\hline & 毛の他の改賈 & 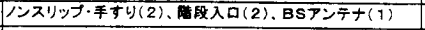 & 5 \\
\hline 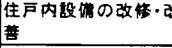 & & & - \\
\hline \multirow[t]{3}{*}{$\begin{array}{l}\text { 可地内付带施設の } \\
\text { 洒 }\end{array}$} & 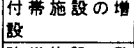 & 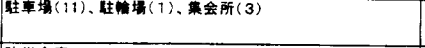 & 15 \\
\hline & 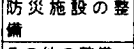 & 防災倉萑 & 2 \\
\hline & その地の嶅莆 & 团地内道路改橴 & 1 \\
\hline その他 & & 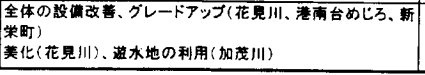 & - \\
\hline
\end{tabular}

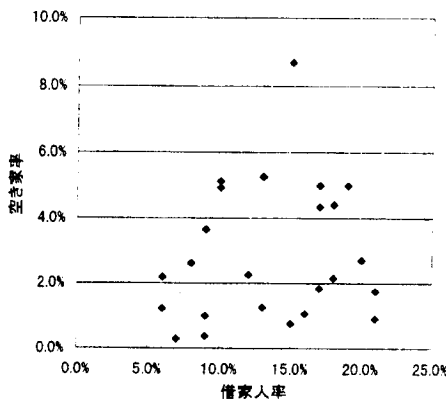

図 4 空き家率と借家人率

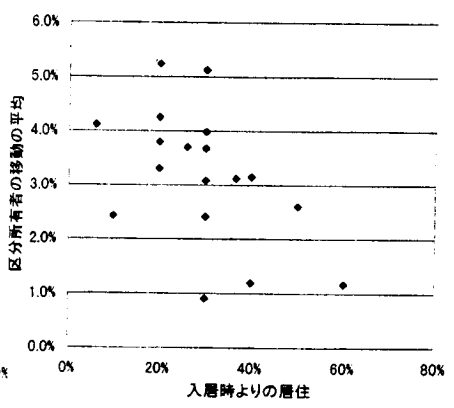

図 5 移動率と入居時加5の居住者率 


\section{3. 調查対象団地の特徽}

居住者動向に影響が大きかったのは立地条件（交通と周辺環境）、 建設年度、住戸規模で、団地規模仕今回の範囲ではほとんど影響な かった。そこで調查団地を、立地条件と建設年度、住戸規模をもと にプロットし、修繥状況 ${ }^{8)}$ と管理組合活動の特徵を重ね合せると、 図6のように表現することができる。

40年代の公団分譲は、田围や山林、埋め立て地などに、離れ島の ように開発された。最も典型（多数派）的な団地は、(1)建設年度が 荤くなるほど不便な場所へ立地するようになり、(2)賃貸との併存も 多い。(3)中古価格が安く、現在ほとんどが1000万円以下である。(4) 当初からの居住者は 3 割前後だ、転居率が低くなって定住傾向が 見られる。(5)管理組合活動は活発で、建物・外構の維持管理状況は 良い。(6)樹木が大きく（３組合は大きすきと回答）緑豊かな環境で、 外壁も補修されている。駐車場はかなり增設され、集会所も改装、 建て替元、增筑をしているところが多い。幊貸併設団地では、貸貸 からの移動者が多い。団地全体の老齢化は全体的にはそれほど進ん でおらず、50才代夫婦が中心で、子世代は20〜24才が多い。親世代 は定年が近く、現在の住宅を補修しつつ長く住むこと考えているよ うだ。等価交換による建て替えは立地条件から見て無理である。 図左寄りの交通の便が良い団地も、入居当初より良いのではなく、 京葉線、武蔵野線、などの新線の駅が近くなったためである。

借家型は、(1)周囲に工場やオフィスビルがあって貸貸需要が多い。 (2)貨貸住宅との併存でない。(340年代初期に分譲され、(4)住戸規模 は混在し、(5)中古価格は高い。(6)借家率が高く、年齢、所得階首、 家族形態、居住理由が種々な居住者が含まれ、当初からの居住者は 1 割程度である。移動率が高く、貨貸需要に恵まれているため、移 転者の中には一定率の家貨収入を得ようとする人があり、今後も借 家率は增加すると思われる。各居住者㬝の混在で、管理組合活動は 困難である。周辺の市街化が更に進行すれば、等価交換前提の再開 発が可能になる。

建て替え型は、(1)交通の便が良く、(2)借家人比率は高いが、(3)周 囲が団地で貸貸需要はそれほど多くない。(4)增築した住戸以外は住 戸が狭い。当初からの居住者は典型ほど多くないが、現在の中心的 家族棈成は定住型の50才代である。移動する人は移動してしまった ようである。中古価格はそう高くない。建て替えは過去にも検討さ れ、今後も検討予定のところが多いが、バブル崩壊で等価交換が難 しくなり止まっている。今後景気が回復し、同等の条件下にある他

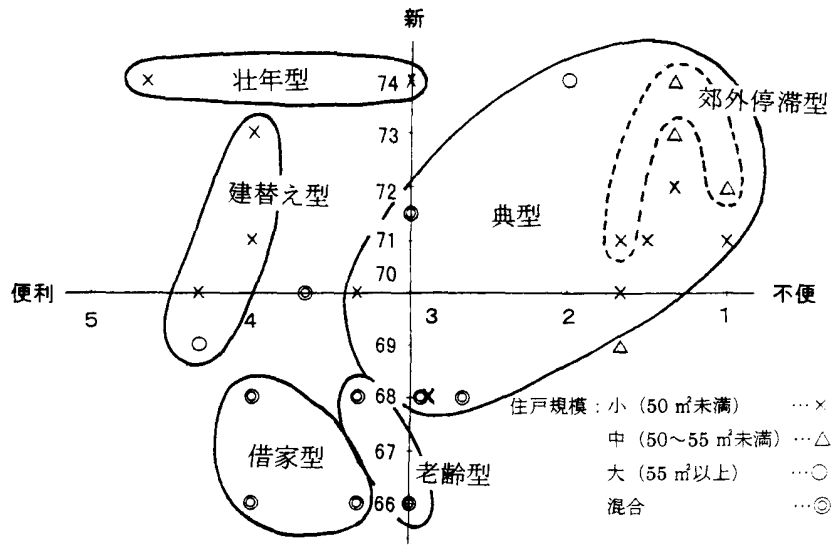

団地の建て替えが成功すれば、動き始める可能性がある。

郊外停渔型は、家族構成や定着性の高さは典型と同じだが、(1)交 通の便の悪さと(2)修䋨積立金の低さ（組合活動の不活発さ）が違つ ている。(3)住戸は狭く。(4)当初からの入居者が多い。所有権の移動 が少なく (1.2\%平均)、中古市場における売買成立件数も少ない。 壮年型は、(1)交通の便は中程度、(2)管理組合活動が活発で、(3)修 䋨積立金も充分である。(4)分譲年度が遅く45～50才代が多いが、(4) 当時としては床面積が狭かったため、当初入居者の年齢が高くなく 定着型である。借家人も多い。団地内の植栽、外構等の整備が進ん で、各住戸も花を飾るなど、団地全体が明るい䨌囲気である。老朽 化が急進する事はない。

老齢型は典型の中で最も初期の団地である。(1)老齢化が進行し定 年後の人が多い。(2)当初からの入居者が多く今後も住み続けられる 限り住むつもりの人が多い。(3)交通の便は中程度だが等価交換でき る程ではない。(4)維持管理の方法が確立していない時期だったので 管理組合活動の差が大きい。(5)中古価格が安く転居してくる人に定 年後の夫婦もいる。

\section{4.まとめ}

昭和40年代の郊外大規模分譲集合住宅団地は、全体として、1)全 国のマンション ${ }^{6)}$ に比して、大規模修繥の回数と間隔、修繥積立金 額など維持管理状態はかなりしっかりしている。2)小規模な改善を 積み重ね、緑豊かな環境を保持しているが、建て替えや大改善など 積極的な動きは少ない。3)ていねいに維持管理しながら長く住み続 けようとしている団地が多い。4)老齢化は進行しつつあるが、まだ 深刻な事態には至っていない。5)立地条件や住戸規模等の違いから 団地によって居住者動向や管理組合の活動など違いが明白になって きている。6)早晚建て替え問題が生じるはずだが、再生への取り組 みはほとんど見られない。

謝辞 ご多忙の中、面倒な調查にご協力いただいた各管理組合の理 事長並びに事務局の皆様に心より感謝申し上げます。

\section{参考文献・注}

1)松本恭治: 郊外の大規模分譲集合住宅団地におけるフィルタリンク構造の分 析, 日本マンション学会第 6 回大会研究報告集 严成 9 年 PP.360 369 2)山本育三，松本恭治ほか：経年的にみた公団分譩集合住宅の維持管理に関す る研究（その1〜その 5)，日本建築学会学術講演梗概集・計画系，1982 小泉克彦, 岩本利明 : 質の高い居住環境の維持管理に関する調查, 住宅都市 整備公団調查研究期報, Vol.98,PP.49-61,1992.12

3)本報告では大規模を500戸以上と定義し、郊外とは東京を中心とする20k圈 外とする。八潮伊草団地は20kn圈内だが交通の便から対象に含めた。 4)ある団地では、大幅な駐車場を增設後、駐車代金を共同浴場やクラブハウス などの施設建設に当てていたが、希な例である。

5)各団地の住户規模と共益費及び修縉積立金との間に比例関係は見られない。 6)平成 5 年度マンション総合調查結果報告書, 平成 6 年 3 月, (財)マンション管理センター

7)計画修綪工事の進め方(改訂版), 平 7 年11月, (財)マンション管理センター 8)修綪状況は以下の項目を点数で評価し合計して判断した。修繥履歴（工事内 容で重み付け）と費用調達方法、修結樍立金の現状と戸当残額、增額回数。

[1998年 6 月25日原稿受理 1998 年11月 4 日採用決定］ 